\title{
International Language and the Everyday: contact and collaboration between C.K. Ogden, Rudolf Carnap and Otto Neurath.
}

\author{
James McElvenny \\ james.mcelvenny@mailbox.org
}

This is the manuscript of my paper in the British Journal for the History of Philosophy (2013) 21.6: 1194-1218. Cite the published version!

https://doi.org/10.1080/09608788.2013.825761

\begin{abstract}
Although now largely forgotten, the international language movement was, from the 1880 s to the end of the Second World War, a matter of widespread public interest, as well as a concern of numerous scientists and scholars. The primary goal was to establish a language for international communication, but in the early twentieth century an increasing accent was placed on philosophical considerations: wanted was a language better suited to the needs of modern science and rational thought. In this paper, we examine the example of the English scholar C.K. Ogden's international language Basic English and his efforts to win the Vienna Circle philosophers Otto Neurath and Rudolf Carnap over to the project. Basic is shown to be an implementation of key ideas in Ogden's philosophy of language, ideas shared to a large extent with Neurath and Carnap. This we see through an examination of their unpublished correspondence, as well as through the collaboration that emerged between Ogden and Neurath, in which Neurath's Isotype, a system for graphically representing statistical data, became closely aligned with Basic. Through the ideas and endeavours we investigate here, we gain a new perspective on this crucial period in the history of analytic philosophy.
\end{abstract}




\section{Keywords}

Vienna Circle; Otto Neurath; Rudolf Carnap; C.K. Ogden; international language; epistemology; Isotype; BASIC English; protocol sentence debate; history of ideas

\section{Introduction}

Largely vanished from the current view of the intellectual scene of the first half of the twentieth century is the international language movement, a vibrant stream of plans and projects aimed at establishing a medium for international communication. Entering the general public consciousness in the 1880 s, the international language movement reached its climax in the first decades of the twentieth century, only to decline in the wake of the Second World War. During this peak period, the international language problem received ever more attention from scientists and scholars who sought not only a means for overcoming the curse of Babel, but an improved language, better suited to the needs of science and rational thought. For many, the goal was to create a language in the image of contemporary philosophy. In this paper we observe these developments as manifested in the international language project BASIC English (an acronym: 'British American Scientific International Commercial English') proposed by the English scholar C.K. Ogden (1889-1957). We look at Ogden's contact with the Vienna Circle philosophers Otto Neurath (1882-1945) and Rudolf Carnap (1891-1970), his efforts to win them over to the Basic cause, and the collaboration between Ogden and Neurath that resulted.

We begin in section 2 with a sketch of Ogden's Basic, its place in the international language movement and the philosophy of language that stands behind it. In section 3 we then compare Ogden's approach to the philosophical and political ideas of Neurath and Carnap. These come into clearer relief in section 4, where we examine the interaction between Ogden, Neurath and Carnap as revealed by their extant correspondence. Finally, in section 5, we see how Neurath's 'Vienna Method of Picture Statistics', a graphical technique for representing statistical data, became, through collaboration with Ogden, 'Isotype: international picture language', a contribution to the international language movement, deeply rooted in Neurath's philosophy. We see how Basic, and the collaboration between Ogden and Neurath that grew out of it, reflect the faith Ogden, Neurath and, to a certain extent, Carnap placed in the 'everyday', variously conceived: they sought to improve everyday life by building on the everyday language that describes everyday experience. The interest shown here by Carnap and, even more so, Neurath in the practical applications of their philosophy illustrates their engagement in contemporary social issues, an aspect of the Vienna 
Circle's history that was for a long time forgotten and has only recently begun to receive attention.

\section{Basic English and word economy}

Although Ogden had been long concerned with the international language problem, the first published hints of his own project appeared only in 1927 (Ogden 1929a:5; Richards 1943:xliii, 2223). By this time the international language movement - which first became an issue of mainstream interest in the 1880s with the advent of Volapük and, a decade later, Esperanto (see Haupenthal 2005) - had reached maturity and a general pattern had emerged that most major language projects followed: the average international language of this era sought to emulate Esperanto (Zamenhof 1889 [1887]; 1905), which had proven its practical efficacy and more or less come to dominate the movement. On this model, the international language should be a sort of artificially constructed pidgin of the major European languages, taking from them its vocabulary and grammar and moulding them into compromise form (cf. Schubert 1989:11-12, 15-16). With the increasing involvement of scientists and scholars in the movement, philosophical considerations in the design of language projects took on an ever more important role. ${ }^{1}$ Ogden's Basic is both typical and highly unusual in this context: it subscribes to the goal of engineering a better language on philosophical principles, but at the same time abandons all efforts at finding a fair compromise that works to no single nation's advantage and avoids national jealousies. Basic takes the English national language as its sole basis, since, Ogden (1931:28) argued, it is already 'the most adaptable language the world has yet seen'. Basic merely seeks to exploit and improve on this 'British American' asset for the benefit of the whole world. One of the central improvements Ogden proposed was to firmly anchor the language in everyday experience.

According to Ogden, the key to solving the international language problem is to offer a restricted vocabulary of the most necessary words that would force users of the language to analyse their expressions and spell out what they mean. This is a conviction deeply rooted in his thought. In The Meaning of Meaning (Ogden and Richards 1989[1923]) - the most comprehensive statement of Ogden's philosophy of language, co-authored with his friend, the literary critic I.A. Richards (18931973 ) - the target is 'word-magic', a term they used to describe a superstitious belief in the power of words that leads, among other undesirable consequences, to philosophical confusion (see chapter

\footnotetext{
There are numerous histories of the international language movement and surveys of international language projects with varying degrees of discussion of their historical background. Among more recent scholarly studies are the survey Blanke (1985) and the historical account Forster (1982). See chapter 4 of Blanke (2006) and the accompanying bibliography for an up-to-date guide to the interlinguistic literature.
} 
2 of Ogden and Richards 1989[1923]). Their remedy for word-magic is the 'method of definition', the unpacking of words' references to find what they actually mean, if anything. Basic, asserted Ogden, pursues this principle to its conclusion: it offers a practical means of encouraging definitions with its core vocabulary of 850 'scientifically selected' words (Ogden 1929a:1; 1933[1930]:1). Over the following years, Ogden came to tie these ideas to the thought of the English Utilitarian philosopher Jeremy Bentham (1748-1832), whose champion he became and to whom he attributed most of the insights informing the development of Basic (e.g. Ogden 1932a; 1932b). For the most explicit and comprehensive formulation of the theory behind Basic, however, we must turn to Ogden's assistant, Leonora Wilhelmina Lockhart (1906-1987), and her theory of ‘Word Economy' (Lockhart 1928; 1931a).

We can be sure that Ogden shared the views Lockhart expressed: he enthusiastically endorsed what she had to say (see his preface to Lockhart 1931a:7-8), and much of her wording resembles his own. Lockhart also shared Ogden's combative tone in championing the cause of the 'scientific' study of meaning and symbolism and berating those other scientists who concern themselves with language, the philologists and the phoneticians, whom she saw as having neglected the study of meaning (Lockhart 1931a:12). The best approach, argued Lockhart, lies in the 'science of symbolism' that has grown out of The Meaning of Meaning and manifests itself in Basic. This gives us the means to make language 'a more precise instrument of thought' (ibid.:56). In fashioning this instrument 'we are faced with the [...] problem of reduction' (loc. cit.). Reduction can be understood as grammatical reduction and reduction of words, the elimination of complex rules of syntax and morphology and the elimination of excessively fine-grained and compositionally inscrutable words respectively. English provides the perfect basis for both, due to its 'analytic tendency', manifested chiefly in its lack of the unnecessary intricacies and irregularities of inflection found in the more 'synthetic' Continental languages. This lack of morphology grants English an inventory of simple radical elements that may be freely arranged to create any analytic expression (ibid.:23; cf. Ogden 1931:28).

Lockhart did not see 'analysis' of an expression as an end in itself: analysis is only useful insofar as it helps to establish the connection between a word and its referent. But analytical expressions are generally better for establishing references, since they allow us to 'systematize our knowledge', and so are perhaps the best 'antidote to the habit of using words without adequate reference' (Lockhart 1931a:56-57). The British philosopher John Wisdom (1904-1993), in writings undertaken at Ogden's prompting (Wisdom 1930:11, note 1), argued against these views as he 
found them in the works of Ogden's idol Bentham (Wisdom 1930; 1931). He insisted that there was a fundamental difference between 'analysis' and 'interpretation', confused by Bentham and likeminded scholars. Wisdom essentially took analysis to be the analysis of a concept, through which the fundamental elements and structure of facts in the world are revealed, while interpretation he treated as merely establishing what particular words mean; through interpretation we merely replace one set of words for picking out a referent with another, without necessarily offering a more philosophically motivated description. ${ }^{2}$ Lockhart (1931b) rejected Wisdom's distinction and claimed that it presupposed the possibility of some sort of ultimate, 'metaphysical' knowledge beyond that which can be expressed verbally. According to Lockhart, there are no 'god-given concepts' (Lockhart 1931a:58). Every system of analysis has its own validity and can always be reduced to a lower explanatory level:

[E]ven within the confines of a single language, the basis of definition is determined by the particular aspect of knowledge with which we are, for the moment, concerned. The 'species' on which the botanist's classification is based may be resolved in the chemist's test tube into a variety of substances ; and the simple elements of the chemist's world will be turned by the physicist's electroscope into a complex system of energy. Each account of phenomena has its legitimate starting point. And as there seems to be no means of escape from the bias attaching to individual systems, linguistic or scientific, it is difficult to see how an absolute analysis of the constituents of the universe is possible.

(Lockahrt 1931a:51-52)

The best level for analysis outside the specialised sciences then is that of our everyday phenomenal experience: 'If language is to consult human convenience - and being a tool fashioned by the human mind for its own purposes, this can scarcely be denied - it should symbolize objects, as far as possible, at the level of our perceptions. Facts that cannot be inferred directly from contact with the object should not be covered by the unit symbols' (Lockhart 1931a:60; cf. Walpole 1937 and Myers 1938). Ogden, in endorsing this view as he found it in Bentham's writings, answered the critiques of Wisdom and fellow logical atomists with the following words:

Bentham believed that language must contain fictions in order to remain a language, i.e., that a

\footnotetext{
2 The Cambridge philosopher Susan Stebbing (1885-1943) later came to identify, in terms reminiscent of Wisdom's critique, the lack of recognition between different kinds of analysis as a hallmark of Viennese logical positivism in contrast to the philosophy practised in Cambridge (see Stebbing 1933; see also Beaney 2003; Milkov 2003).
} 
language which "mirrored" reality would be impossible. [... W]e could not talk of the analysis of a given proposition. This is the real bone of contention between the logic-analystic temperament and the technological approach of Bentham. The latter realized that the problem is eminently a practical one - the classification of thought by simplifying and revealing the structure of language ; and therefore a task for whose performance no eternally valid rules can be promulgated. The logico-analysts postulate an ideal language - perfect even in its well disposed irregularities which requires methodical articulation in accordance with a preconceived metaphysical scheme.

(Ogden 1932b:11)

The sentiment Ogden expresses here, as we will now see, matches exactly that which Neurath voiced at the same time within the Vienna Circle.

\section{The everyday versus metaphysics}

As the chief representative of the so-called 'left-wing' of the Vienna Circle, Neurath was in the vanguard of a combative and politically engaged assault on traditional philosophy. In the Circle's manifesto (Verein Ernst Mach 2006[1929]) - a text with multiple authors, among the most significant of whom were Neurath and Carnap (see Uebel 2008:77-87; cf. Haller 1993:70; Stadler 1997:372) - the wissenschaftliche Weltauffassung, or 'scientific world conception', is pitted against the confusions and deceptions of 'metaphysics'. This was not simply an academic project, but an effort 'to fulfil a demand of the present day $[, \ldots]$ to fashion tools of thought for the everyday, not only for the everyday of scholars, but also for the everyday of all who in whatever way are involved in consciously working to shape our lives' (Verein Ernst Mach 2006[1929]:10-11). ${ }^{3}$ The professed goal was to make a better world and a better life through the enlightenment science brings. This endeavour was in contrast to the more staid attitude of the Circle's 'right-wing', led by Moritz Schlick (1882-1936), which was at home and comparatively at peace in the ivory tower (see Stadler 1997:546-556). Although counting himself as part of the left-wing (Carnap 1963:57), Carnap was always more moderate than Neurath, both in terms of philosophical doctrine and wider social and political engagement (cf. Carus 2007:243).

By the time Ogden made contact with Neurath and Carnap in 1933, the two Vienna Circle

\footnotetext{
The complete sentence reads in the original: 'Der Wiener Kreis glaubt durch seine Arbeit im Verein Ernst Mach eine Forderung des Tages zu erfüllen: Es gilt, Denkwerkzeuge für den Alltag zu formen, für den Alltag der Gelehrten, aber auch für den Alltag aller, die an der bewußten Lebensgestaltung irgendwie mitarbeiten.' An idiomatic English translation that does not quite capture the central place of the word Alltag in this quotation can be found in Neurath and Cohen (1973:305).
} 
philosophers had settled on varying versions of a doctrine Neurath called 'physicalism' as their answer to metaphysics. At heart physicalism hinges on the possibility of translation: what distinguishes a scientifically valid statement from a meaningless statement of metaphysics is that the scientific statement can be translated into a language that describes everyday phenomenal experience. The statement of experience can then be confirmed or disconfirmed, a possibility not available to the untranslatable metaphysical statements. This principle of intertranslatability allows further for the 'unity of science', the free co-operation and communication among scientists, breaking down the disciplinary boundaries that presently separate them, a goal that Neurath (e.g., 1931:618) first proposed and which achieved currency within the Circle. The discussion in which Neurath and Carnap developed and refined physicalism is known as the 'protocol sentence debate', named after the 'protocol sentences' in which observations are recorded, as in a scientist's 'protocol' of their experiment (see Uebel 2007). Neurath drove the debate with his objections to the prevailing atomistic epistemology of the Vienna Circle's right-wing, which closely followed the evolving teachings of Ludwig Wittgenstein (1889-1951; see chapter 4 of Uebel 2007; Carus 2007:239-251).

Physicalism finds its classical exposition in Carnap's (1934[1931]) essay 'Die physikalische Sprache als Universalsprache der Wissenschaft' (The physical language as the universal language of science), an essay that was published in English translation by Ogden in 1934 under the title The Unity of Science. At the centre of Carnap's physicalism as presented in The Unity of Science is the 'physical language'. This is indeed the language of the scientific discipline of physics, although not necessarily in the form it has today or in the form it has had in any historical period (Carnap 1934[1931]:54). The defining property of this language is that it talks objectively about physical entities in the world in quantitative terms (ibid.:52-67). That is, it talks of goings on in the world in a mathematically precise way independent of the perceptions of any individual. It is possible to verify any statement of this physical language by translating it into the 'protocol language' - an idealised language that directly records the experiences of an individual observer - and there are as many of these protocol languages as there are observers. The phenomenon comes first and the analysis later, argued Carnap (ibid.:46-47), turning to the then recent research of Gestalt psychologists.

Carnap took the physical language as his basis for two reasons. First, it is objective, or rather inter-subjective. That is, it talks about the world in absolute terms, divorced from the perspective of any single speaker. This is in contrast to the protocol languages, each of which refers to the private experience of the individual and so is not available for public discussion. Second, so claimed 
Carnap, every statement in every scientifically valid language can be translated into the physical language. Statements in any of the 'sub-languages' of chemistry, biology, psychology, sociology and so on - that is, in any of the genuine sciences - can all be translated into the physical language (Carnap 1934[1931]:67-74). But not every statement in the physical language can be translated into one of the sub-languages. The physical statement may deal with a subject matter that lies outside the scope of any given sub-language: a statement that could be translated into chemical terms may not be translatable into sociological terms, for example. It is this possibility of translating any statement from the sub-languages into the physical language that makes it the 'universal language' that guarantees the 'unity of science' as a single undertaking, and simultaneously excludes everything that is not scientific - these are the constructive and exclusionary sides of the scientific world conception (ibid.:96).

Neurath, however, saw Carnap falling into a metaphysical trap. In Carnap's protocol language ' $[\mathrm{t}]$ he simplest statements [...] refer to the given, and describe directly given experience or phenomena, i.e. the simplest states of which knowledge can be had' (Carnap 1934[1931]:45). For Neurath, by contrast, there is no 'given'; every observation involves the application of some sort of theory, a notion frequently associated with the French physicist and philosopher of science Pierre Duhem (1861-1916), whom Neurath (1983[1932]:98) cited as an inspiration, among others (cf. Cartwright et al 1996:111-131). There is therefore no clean separation between the protocol language and the physical language: the two are distinguished only in that the protocol language makes reference to the observer, while the physical language does not (Neurath 1983[1932]:93). All we have, according to Neurath, is the 'trivial language' that is handed down to us from previous generations and is full of imprecise, unanalysed terms, which Neurath called Ballungen (glossed as 'verbal clusters' in Cohen's English translation). Instead of pursuing the inevitably fruitless goal of reaching an ideal language, we should simply seek to clean the everyday language of its metaphysical terms (ibid.:91), which will give us a 'universal jargon', the best result that we can ever hope for (ibid.:92). This is the view that Neurath summed up so elegantly in his well-known Schiffer [sailor] metaphor, a recurring motif in his writings (see Cartwright et al 1996:89-166 for its history):

There is no way to establish fully secured, neat protocol statements as starting points of the sciences. There is no tabula rasa. We are like sailors who have to rebuild their ship on the open sea, without ever being able to dismantle it in dry-dock and reconstruct it from the best components. Only metaphysics can disappear without trace. Imprecise 'verbal clusters' ['Ballungen'] are somehow always part of the ship. If imprecision is diminished at one place, it 
may well re-appear at another place to a strong degree.

(Neurath 1983[1932]:92)

In The Unity of Science Carnap was clearly struggling with objections of this sort. He was prepared to acknowledge Neurath's point as a practical difficulty, but not as an insurmountable theoretical barrier. There may be Ballungen in actual protocol languages, but that does not mean that there can be no 'primitive protocols' in which they have been entirely eliminated (Carnap 1934[1931]:44). In the face of Neurath's critique of The Unity of Science, Carnap (1932) accepted the possible existence of many different kinds of protocol languages, the beginning of his subsequent project of 'logical tolerance', which focuses on the technical details of translation between languages rather than trying to establish a single epistemological foundation (see Carnap 1937[1934], a work also published in English by Ogden).

For both Carnap and Neurath, the epistemological foundation of science was to be found in the 'everyday'. For Carnap this meant personal phenomenal experience, even if expressing that experience required a special technical language, but Neurath's conception was even more radical. He could not imagine pure experience unmediated by the accumulated interpretations handed down to us in our everyday language: we are left having to gradually and continually strip these out of our language to approach a better understanding of the world.

\section{Contact}

In both cases Ogden's contact with Neurath and Carnap was initiated by him and begins with a proposal. Neurath he pursued because he wanted to develop a visual education method for Basic; Carnap because he wanted to secure the English translation rights to Carnap's recent philosophical papers, which were already being keenly discussed in English-speaking circles. In both instances Ogden was successful. A great deal of the correspondence between Ogden, Neurath and Carnap is made up of back-and-forth negotiations - which often degenerate into brusque exchanges regarding such distasteful topics as fees, royalties and copyright. But amid these exchanges their common philosophical and linguistic interests still emerge as topics of discussion. We see agreement on core philosophical points and Ogden's unwavering efforts to win Neurath and Carnap over to the Basic cause.

Most of Neurath's earliest correspondence with Ogden, beginning in 1933, appears to be lost, 
and this means the loss of his initial reaction to Basic in his own words. ${ }^{4}$ But from Ogden's side of the correspondence it can be seen that Neurath responded with interest to Basic: Ogden writes, 'The Basic books named in your letter went all to you on October 7 (registered), and I am hoping that they are now in your hand' (Ogden to Neurath, 17 October 1933), suggesting Neurath had expressed an interest in these books in his previous letter. Apart from their subsequent collaboration, there are other indications that Neurath was impressed by Ogden and his Basic. In 1935 Neurath made Ogden a member of the international organising committee for the Unity of Science congresses (recorded in Neurath 1938:26; Stadler 1997:406), and invited him to speak at the 1937 Congrès Descartes in Paris, the Ninth International Congress of Philosophy, as well as inviting both Ogden and Lockhart to talk at the 1941 Unity of Science congress on 'the analysis of language making' and word economy respectively (the invitations are dated Neurath to Ogden 10 June 1937, 26 September 1941; Neurath to Lockhart 26 September 1941; Neurath also sent invitations to participate in the 1939 congress: Neurath to Ogden, 7 February 1939, 11 April 1939). Neither Ogden nor Lockhart presented at these conferences, however. The reason why remains an open question, but the invitations from Neurath imply that he wanted to encourage their program or at least that he thought it was worthy of wider discussion and debate in such a high-level forum. A later letter from Neurath to Lockhart suggests that he found Basic English a useful source for his own work and had a desire to learn more about its historical and philosophical background:

\begin{abstract}
I had more than once [in recent lectures at Oxford, Nottingham, London and Exeter] an opportunity to discuss Basic English problems. Let me repeat how much I appreciate the General Basic Dictionary. It helps me really in preparing my Scientific Universal Jargon and to understand better some problems of Language Making. Where could I find a report, [sic] how Basic has been made? The history, so to speak, of this language?
\end{abstract}

(Neurath to Lockhart, 19 July 1941) ${ }^{5}$

We have a more detailed record of Carnap's reaction to Basic and Ogden's wider thought in their extant correspondence. In his reply to Ogden's initial letter, Carnap displayed some curiosity about

\footnotetext{
4 The Ogden-Neurath correspondence is kept in the Ogden collection of the McMaster Archives and the Neurath collection of the Noord-Hollands Archief. While there are letters from Ogden to Neurath dating from 1933 in the McMaster Archives, the earliest letters from Neurath to Ogden held there date only from 1937; the letters in the Noord-Hollands Archief, from both Neurath and Ogden, cover only the period 1941-1944 (see Fabian 1996:352). The Ogden-Carnap correspondence is kept in the Ogden collection at McMaster.

5 The 'Scientific Universal Jargon' that Neurath refers to here is his own effort to develop an appropriate universal language for science (see section 3).
} 
Basic, prompted by his existing interest in international languages, in particular Esperanto, and Neurath's enthusiastic comments on Basic:

\begin{abstract}
When Neurath was here recently he spoke enthusiastically about your "Basic English". I'd be very grateful if you could send me something in the way of orientation. For many years I've had a lively interest in the problem of an international auxiliary language. In terms of theory I'm especially interested in the logical side of this problem, the question of logical syntax. But I've also been involved with the practical aspects (I can speak Esperanto, but am not dogmatically attached to this system). I consider an auxiliary language especially worthwhile and necessary for international relations in science.
\end{abstract}

(Carnap to Ogden, 7 December 1933) ${ }^{6}$

In response Carnap received most of the Basic literature published at that time. Unwilling to allow any opportunity for propaganda to slip by, Ogden pointed out in his letter of 11 December 1933 that '[t]his letter is itself all in Basic English, and within the rules of the $\underline{\mathrm{ABC}}$ [of Basic English].' He also frequently signed himself 'Yours (in Basic) very truly, C. K. Ogden'. Over the next month, Carnap and Ogden acknowledged the common points in their philosophy. In a copy of The Meaning of Meaning he sent Carnap, Ogden underlined the point at which he and Richards give their assessment of 'metaphysics'. Carnap replied: 'From the marked point (p.222) I see, that our views about metaphysics will be in good agreement. With great interest I will see the details of your views' (postscript dated 30 December 1933 to a letter from Carnap to Ogden, 29 December 1933). The 'marked point' was most probably in the second paragraph on page 222 of the third revised edition, published 1930, where Ogden and Richards address 'metaphysics', and comment ' $[. .$.$] the$ set of confusions known as metaphysics has arisen through lack of this true grammatical approach, the critical scrutiny of symbolic procedure' (Ogden and Richards 1989[1923]:222; same page as the edition of 1930; emphasis original).

Despite the early exploratory enthusiasm he expressed in his first exchanges with Ogden, Carnap's 'lively interest' in international auxiliary languages did not develop into the sort of support

\footnotetext{
6 Original: 'Als Neurath kürzlich hier war, sprach er auch mit Begeisterung von Ihrem "Basic English”. Ich wäre Ihnen sehr dankbar, wenn Sie mir etwas zur Orientierung schicken könnten. Ich bin seit vielen Jahren lebhaft interessiert an dem Problem einer internationalen Hilfssprache. Theoretisch interessiert mich besonders die logische Seite dieses Problems, die Fragen der logischen Syntax. Aber auch praktisch habe ich mich damit befasst (ich kann Esperanto, bin aber nicht dogmatisch festgelegt auf dieses System). Ich halte besonders für die internationalen Beziehungen auf dem Gebiet der Wissenschaft die Verwendung einer Hilfssprache für erstrebenswert und notwendig.'
} 
for Basic that Neurath showed. Much of Carnap's Christmas holiday of 1933, which followed shortly after his first contact with Ogden, was spent reading and digesting the books Ogden had sent him, and in his first letter after Christmas, whose opening could have served as a testimonial for Basic, he demonstrates an interest in the language that would have certainly pleased Ogden:

[T] he best and most pleasing things of all I got this Christ-birthday are the books you sent me so kindly. It was very interesting for me to get knowledge of your system of Basic English. And here you see the fruit of my reading. At school I was learning much Latin and Greek but very little English. Later I was sometimes reading English books and papers of my science range, but had no chance for talking and writing. My knowledge of English is so bad, that I not ever had the heart for writing an English letter. And now I am very happy to be able to do so by help of Basic English.

(Carnap to Ogden, 29 Dec 1933)

Carnap goes on to endorse Lockhart's theory of 'word economy'. He writes: 'I am in full agreement with your (and Miss Lockharts [sic]) statement about word economy. I have the belief: if there would be a competition among the philosophical books and papers in German for the use of the least number of words, I possibly would be at the top' (Carnap to Ogden, 29 December 1933).

But the winner of the winter holiday remained for Carnap Esperanto. In his next letter, he gave Ogden's permission to use his name on a petition in support of Basic - 'I give you with pleasure my approval to put my name on the list of those who give their support to Basic' (Carnap to Ogden, 7 February 1934) - but maintained a preference for Esperanto, which, he writes, 'is still more simple than Basic. (Much more, in my opinion, than you seem to see; what you say at some places f.e. [for example] about Esperanto is not quite right; but this question is not very important)' (Carnap to Ogden, 7 February 1934). In practice, however, continued Carnap, perhaps only a language like Basic that is derived from a natural language has a chance, as opposed to an 'artificial' language like Esperanto, which is further removed from any existing natural language (see Ogden 1935 for Ogden's arguments against 'artificial' languages). Carnap backed away from putting too much weight on such practical concerns; he only countenances such issues, he writes, because of the arguments of his pragmatic friend Neurath:

[W] see from the facts - or at least it seems very probable - that the much greater number of men are not ready to make use of a not-natural language system; they have even a disgust at such a one. For this reason a part language [i.e. 'sub-language', in a similar sense to this term's use in physicalism (see section 3 above)] of a natural language has much more chance to be taken in use 
by a great number of men in the near future, on the condition that this language is simple enough (though not so simple as a constructed one). Now, in my opinion, your Basic system is in this condition. It is possible to make use of it even at present in the relations to a very great number of men. You are right that this gives to Basic the greatest chance of beeing $[s i c]$ the help-language [i.e. auxiliary language] of the future. I will say you openly, that I have a feeling of regret about the fact that a constructed language - though much better, if seen from the angle of theory - has no chance in fact. But facts have more force than feelings; and so we have to take Basic. (I myself am a man more of theory and system than of fact and doing. That I am looking now at the question of Basic from the angle of fact is chiefly the effect of the words of my friend Neurath).

(Carnap to Ogden, 7 February 1934; underlining original)

In his reply, Ogden implied that he and Carnap were actually in agreement on the question of Basic versus Esperanto (12 March 1934): 'Delighted to have your signature. [What you say is what we mean by "not satisfactory for the purpose"; i.e. "men are not ready to make use of a made-up language.’]' Note that Carnap did not consider Esperanto perfectly logical, however:

In consequence of the unsystematic and logically imperfect structure of the natural worldlanguages (such as German or Latin), the statement of their formal rules of formation and transformation would be so complicated that it would hardly be feasible in practice. And the same difficulty would arise in the case of the artificial world-languages (such as Esperanto); for, even though they avoid certain logical imperfections which characterize the natural world-languages, they must, of necessity, be still very complicated from the logical point of view owing to the fact that they are conversational languages, and hence still dependent upon the natural languages.

(Carnap 1937[1934]:2)

By the spring of 1934 Carnap seems to have more or less given up on Basic. He begins his first letter in April with: 'please allow me to write in normal English. My former letters were exercises in Basic, but it takes me a little more time to write in Basic, because of the right selection of words' (Carnap to Ogden 13 April 1934). 'Nevertheless,' he added, 'I would prefer to get your letters in Basic as before, if it does not cause you trouble or loss of time' (ibid.). He announced also to Ogden that he had been invited to deliver a series of lectures in London in October of that year, and so now he had reason to improve his knowledge of 'normal English'. This is in fact the trip when Carnap first made the personal acquaintance of Ogden, later recalling that 'I talked often with C. K. Ogden, mainly about language and logic, his Basic English and international languages' (Carnap 1963:33$34)$. 
Unperturbed, Ogden pursued Carnap further as a potential Basic English speaker. In response to an apparent enquiry from Neurath on the possibility of translating the proceedings of the 1934 meeting of the Unity of Science movement in Prague, he said: 'Carnap himself writes excellent Basic! Why not ask him to be present, for Basic, at the Conference?' (Ogden to Neurath, 22 April 1934). As the date of Carnap's London lectures drew closer, Ogden urged him to consider using some Basic: "Why not do one of your "London Lectures" in Basic? I would be happy to go through a rough copy in the simplest English you are able to send. There would be no need to say that it was Basic till after the event' (Ogden to Carnap, 21 July 1934; underlining original). Here Ogden is urging Carnap to employ one of his favourite ruses for demonstrating the efficacy of Basic: a text is delivered in the language and then at the end, with a flourish, it is revealed that Basic was being used all along, a technique he used himself in Ogden (1943:25). Carnap politely but firmly rejected Ogden's advances, with some attempt at consolation. He felt he would be 'too much restricted' if he had to speak Basic, a suggestion that would have surely irritated Ogden:

\begin{abstract}
Your suggestion of giving one of the lectures in Basic has something attractive about it, and I had thought myself already before about this idea. But I think that this occasion would not be quite convenient, because these lectures contain a lot of technical terms; I should feel to [sic] much restricted, if I were to say these things in Basic. But I am considering the possibility of writing later on a paper and in this case I should be very obliged for your kind help to put it into Basic.
\end{abstract}

(Carnap to Ogden 30 August 1934)

The later published version of these lectures appeared under Ogden's editorship (Carnap 1934; 1935), but in 'normal English', not Basic English. There do not seem to be any extant papers by Carnap in Basic.

The most controversial aspect of Basic in the context of the international language movement was its strident promotion of all that is 'British American' for the benefit of the world, and Neurath and Carnap's reaction to this feature of the project is perhaps informative about their political views at this time. Neurath would seem to have embraced the Anglo-centrism of Basic. In 1942 he wrote to Ogden: 'Since I believe, more or less, in the Anglicization of the world, I anticipate success for BASIC, of course' (Neurath to Ogden, 23 January 1942). By the time he wrote these words, with the Second World War well underway, Neurath had been living in the Great Britain for two years. He had arrived there after fleeing the German invasion of the Netherlands, where he had moved in 
1934 as a result of political developments in Central Europe. Great Britain was Neurath's refuge and the Neurath of the 1940s was a man satisfied with his new English homeland and the AngloAmerican future he anticipated. Ogden and Neurath's correspondence in this period consists mostly of queries from Neurath about the ideas of various classical English thinkers, in particular Ogden's hero, Jeremy Bentham. Ogden indulges him in each reply with pages of information and opinion.

It is not possible to say from the correspondence with Ogden where Carnap stood in relation to the Anglo-centrism of Basic. He later cited two motivations for his interest in international languages: the simplicity of their structure, and 'the humanitarian ideal of improving the understanding between nations' (Carnap 1963:69). In Carnap's mind, as we have seen, Basic did not meet the first of these ideals as well as the more artificial constructed languages, and it is easy to imagine that its Anglo-centrism, with its inevitable elevation of one national culture above all others, would have detracted in his view from its ability to fulfil the second ideal. Basic is not even mentioned in Carnap's (1963:67-71) retrospective survey of constructed language projects. Carnap also fled Central Europe for the English-speaking world, emigrating to the United States in 1935. But unlike Neurath in England, Carnap was not quite so infatuated with his new American home. Among many features that pleased him, he also found much to criticise in the new host culture, such as the 'strong conformism' he detected in American society (see, e.g., Carnap 1963:39). Carnap's perception of American society was no doubt influenced by living through the chilliest parts of the Cold War, where the anti-communist paranoia of McCarthyism led to FBI investigations into the backgrounds and political persuasions of many American academics, Carnap included, a situation examined in detail by Reisch (2005).

Despite initially showing interest in Basic - spurred on by his existing interest in international languages and, in particular, Esperanto - and despite acknowledging many points of similarity between his own philosophy of language and Ogden's, Carnap remained unconvinced of the merits Ogden claimed for Basic. Neurath, however, would seem to have become an enthusiastic supporter, as is reflected in his continuing invitations to Ogden and Lockhart to present Basic and the ideas surrounding it in the forums that he organised, and in his assertions that Basic was informing his own linguistically oriented work. But Neurath's greatest project in this direction is undoubtedly his system of picture statistics, which took on an explicitly linguistic character and acquired rhetoric inserting it into the international language movement in the collaboration that resulted with Ogden. 


\section{International picture language}

The origins of Neurath's system of picture statistics go back to his time as director of the Kriegswirtschaftsmuseum (Museum of War Economy), founded in Leipzig during the First World War to explain to the average citizen the workings of the war economy. Here he developed the first versions of picture statistics as a way of illustrating economic points and principles to a lay audience (see Schumann 1973; Cartwright et al 1996:20). In Vienna, after the war, the system reached new heights of sophistication and systematisation at the Gesellschafts- und Wirtschaftsmuseum (Museum of Society and Economy), which Neurath founded to explain the economic and social policies of the socialist government of 'Red Vienna' to the average citizen (see Neurath 1991[1926]; 1991[1933]). The method became a top intellectual export product, with the lending of exhibits to museums overseas and the establishment of branch museums in Berlin, the Hague, London and Moscow. A typical example of the method from this period can be see in Figure 1 below, which illustrates the different types of economies found in the world and their distribution over various population groups, with their sizes. The toothed wheel represents modern industrial economies, the hammer economies based around skilled trades and agriculture, and the bow and arrow hunter and gatherer economies with primitive agriculture. Each figure represents 100 million people: the outlined figures with hats represent Europeans; the brown figures with turbans represent 'orientals', Indians and Malays; the black figures Africans and 'mulattoes'; and the yellow figures with pointed hats represent 'Mongols'. 


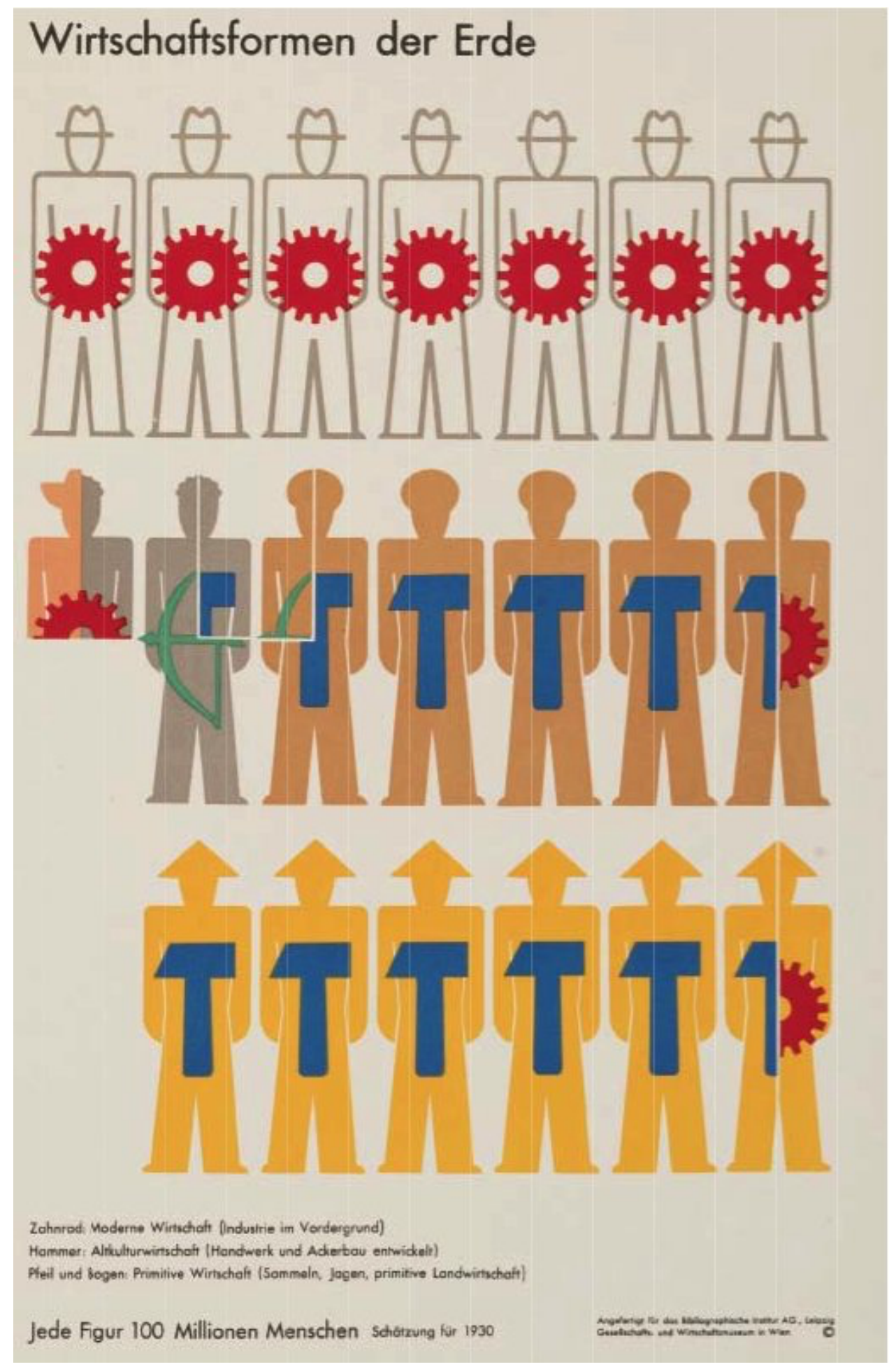

Figure 1. 'Economic systems of the earth' (Gesellschafts- und Wirtschaftsmuseum 1930:97) 
During the 1930s, Neurath developed his picture statistics to deal with an ever wider range of material, going beyond the purely statistical to cover historical narrative and procedural instructions (e.g. Neurath 1936:55; 1939). These developments all occurred in the course of a collaboration with Ogden, during which Neurath's system was rechristened 'Isotype: international picture language'.

It is not entirely clear what lay behind the new designation: even as he introduced the 'international picture language', Neurath was careful to point out that ' $[\mathrm{t}]$ here are simple picture languages in which no other sorts of signs are used. What we have to do with here, however, is a picture language which is not able to give the story by itself, but only with the help of the words of a normal language' (Neurath 1936:16; Marie Neurath 2009:49 makes a similar point). Among later commentators, there are those, such as Müller (1991), who take the designation 'picture language' quite literally and examine it in light of the linguistic theories current in Neurath's milieu; others, such as Burke (2011), dispute that Neurath ever thought of Isotype as a linguistic system, despite the rhetoric that suggests as much. Neurath spoke of the individual symbols as the 'vocabulary' of the system and the method of their combination as the 'grammar', although he always maintained a distance from the implications of linguistic status these terms carry (see Neurath 1936:56).

Whatever the precise status Neurath accorded to the method, it is clear that he saw it as some sort of system of communication and that his approach was deeply bound up with his philosophical convictions about the place of the 'everyday'.

Ogden's influence on Neurath's picture statistics extends to one of the most conspicuous features of the approach, its name. From 1935 onwards the method was called 'Isotype', which, like Ogden's 'Basic', is an acronym: 'International System Of TYpographic Picture Education'; a name, incidentally, that would seem to emphasise the system's pedagogical character rather than its claims to being an international auxiliary language. Marie Neurath (1898-1986; née Reidemeister) - a major proponent of Isotype, coiner of the name, and for many years the companion and later wife of Neurath - recalls the inspiration she drew from Ogden's Basic in the re-branding:

\footnotetext{
The principles of Neurath's system and the ideas that lie behind them are recorded in numerous publications by Neurath. Most of these are collected in Haller and Kinross (1991). Neurath's earliest essay in which the basics of the method can be recognised comes from 1925, shortly after the founding of the Vienna Gesellschafts- und Wirtschaftsmuseum (Neurath 1991[1925]). Neurath (1991[1933]) and (1936) describe the system in detail. Neurath (1996) gives a thorough philosophical and pedagogical justification for the system, and Neurath (2010), his 'visual autobiography', tells the story of the development of the system from the perspective of his personal history. An example of the system in action can be found in Gesellschaft und Wirtschaft (Gesellschafts- und Wirtschaftsmuseum 1930), which contains reproductions from the original exhibits in the Vienna museum. See further the bibliography of Marie Neurath and Kinross (2009).
} 
The two Basic books forced us to find a new name for the method and the formation of the word 'Basic' ('British American Scientific International Commercial') helped in this. One afternoon I sat down and played around with it. I arrived at 'International System Of Teaching in Pictures' Isotip; that did not sound quite right yet, except for the first syllable. It was then only a short step to 'Isotype'; but I did not succeed in finding a good sequence of words for it, and we stayed with the not entirely satisfactory solution of 'International System of Typographic Picture Education'. When Neurath returned in the evening from a meeting in Amsterdam he was pleased with the name, and the next day, asked Arntz [chief graphic designer on the project] to design a symbol for it. Both name and symbol were then published, for the first time, in International picture language.

(Marie Neurath 2009:47)

Marie Neurath's recollection cannot be entirely reliable here. Neurath (1991[1935]), a publication in Dutch, uses the name Isotype and appeared one year before Isotype: international picture language (Neurath 1936), the first of two books published in collaboration with Ogden (the second being Neurath 1937). Isotype: International picture language sets out the system of Isotype and makes a case for its use in pedagogical and international contexts. With the obvious and acknowledged influence that Ogden had on the name 'Isotype', it can be imagined that he, already actively engaged in the international language movement, played a major role in bringing Neurath into the fold and marketing Isotype as an 'international picture language', despite whatever misgivings Neurath may have had about pressing the linguistic status of the method. Even if Neurath wanted to keep the linguistic claims of Isotype within limits, pictures and visual representation certainly occupied an important place in his philosophy of language. According to Neurath, pictures show and can only show - concrete, tangible objects; they are incapable of expressing the abstract entities that populate the metaphysician's world. Pictures perhaps offer the best medium for Neurath's 'universal jargon'. There is freedom in the possible abstractness of the spoken language, but also metaphysical danger; a picture language protects us from this:

What a triumph it was when people freed themselves from the limits of pictographic writing, what a triumph, when language adapted itself flexibly and in multiple forms to the demands of scientific work, when people learnt to master this logical tool. Of course, liberation from the picture led also to diversions, led into the realm of the meaningless. Nominalisation created new problems. In particular the German language leads to such metaphysical diversions; it allows numerous 
statements about 'the nothing that nothings' (Heidegger), about the 'being' - as if the 'being'

could be used in a sentence like the sword or the table. The pure pictographic writing recognises a sword and a table, but no being.

(Neurath 1991[1933]:269) ${ }^{8}$

A picture language could thus serve as 'an education in clear thought' because of the limits it imposes. Just like Basic, which through its restricted vocabulary forces its speakers to analyse and clearly state what they mean in everyday terms, the picture language restricts its users to what can represented graphically:

But in the same way as Basic English is an education in clear thought - because the use of statements without sense is forced upon us less by Basic than by the normal languages, which are full of words without sense (for science) - so the picture language is an education in clear thought - by reason of its limits.

(Neurath 1936:20-22)

The faith in pictures that Neurath shows here was not unique or even original to him. In forming the Basic vocabulary, Ogden preferred nouns to verbs because, among other reasons, nouns generally name things that can be 'pictured', while verbs do not. And in his Basic paraphrases for adjectives he preferred descriptions of the observable behaviour that the target of an adjectival qualification exhibits rather than more elusive qualities (Ogden 1929b:29). For example, says Ogden (ibid::21), rather than describing someone as 'barbaric', we could say that they are like 'the natives of Central Africa or the South Sea Islands'. In Neurath's immediate philosophical milieu, Wittgenstein (1922), in the Tractatus Logico-Philosophicus, proposed his 'picture theory of language', where the 'pictures' we make of the world correspond to it exactly, and Russell also spoke of 'images' in our minds, although he was of course careful to emphasise that he did not necessarily mean visual images (see chapter 8 of Russell 1928). Müller (1991:239-230) specifically warns against looking

\footnotetext{
8 Original: 'Welcher Triumph war es, als man sich von den Schranken der Bilderschrift befreit hatte, welcher Triumph, als die Sprache biegsam und vielgestaltig sich allen Anforderungen wissenschaftlicher Arbeit anpaßte, als man dieses logische Werkzeug beherrschen lernte. Freilich, die Befreiung vom Bild führte auch auf Abwege, führte ins Gebiet des Sinnleeren. Substantivierung gab Anlaß zu immer neuen Problemen. Insbesondere die deutsche Sprache verleitet zu solchen metaphysischen Abwegen, sie gestattet umfangreiche Erörterungen über "das Nichts, welches nichtet" (Heidegger), über das "Sein"; als ob das "Sein" ebenso in einem Satz verwendet werden könnte wie das Schwert oder der Tisch. Die reine Bildschrift kennt zwar ein Schwert und einen Tisch, aber kein Sein.' Here Neurath repeats Carnap's (1958[1931]:69-73) earlier elevation of Heidegger to a paradigmatic example of metaphysical nonsense.
} 
for 'family resemblances' between Neurath's thought and the Wittgenstein of the Tractatus, pointing out the Neurath's extreme negative reaction to the work. Despite their differences, however, we can still observe the quite clear common ground they had, along with others, in treating pictures as direct representations of the world. Müller does not deny this: his warning is probably directed at those who would posit an influence of the early Wittgenstein on Neurath that goes beyond observing their shared positions in their common milieu. Pietarinin (2011:74) believes that Neurath felt pictures 'achieve what they do [...] because of the specific iconic modalities that are more directly linked with cognition than the conventional symbols of natural language are,' an idea he finds 'reminiscent' of C.S. Peirce's views on iconic signs.

'Words divide, pictures unite', first attested in German as 'Worte trennen - Bilder verbinden' (Neurath 1991[1933]:273), and eventually gaining a Basic translation, 'Words make division, pictures make connection' (Neurath 1936:18), is Neurath's repeated slogan for Isotype. It echoes his call for unified science, 'Metaphysical terms divide - scientific terms unite' (Neurath 1987[1933]:23, emphasis original; see also Haller 1993:175-176; Cartwright et al 1996:179), and in so doing classes 'words' with 'metaphysical terms' and 'pictures' with 'scientific terms'. But the 'division' and 'connection' that Neurath had in mind are not necessarily of an international character. The roots of the system are pedagogical: the original purpose was to explain economic details to the uneducated visitors to his museums. Here the division was not between peoples, but between the social classes of a single people. Neurath (1983[1946]:236) later commented that '[w]hen I created "Isotype," together with my collaborators, as an international technique of visual information, I was thinking mainly of the masses, who could now grasp something more than before of the present knowledge of mankind.'

On a purely theoretical level, pictures appealed to Neurath as the basis of a system of communication, especially of scientific communication, because of what he saw as their inherent connectedness to the world. This ensures that they were accessible to everyone, he believed, regardless of their level of education or cultural background. This hope in achieving a more direct symbolic system, and the specific faith in pictures as a means to this end, bound Neurath and Ogden together. Through his collaboration with Ogden, what had started as 'picture statistics' became, even if only in name, an 'international picture language', taking on board Ogden's interests in the international language movement, and emphasising his project's connections to the 'everyday': it is a project aimed at improving everyday life that relies on concrete everyday experience to ensure its efficacy, just like Basic English. 


\section{Conclusion}

The modern international language movement, which had its heyday in the first decades of the twentieth century, occupied many scholars who saw it as an opportunity to find a language designed for the needs of the modern world. Ogden, Neurath and Carnap were all, to varying degrees, involved in the movement. In their extant correspondence we see Ogden trying to win Neurath and Carnap over to his international language project Basic English. Carnap, already an avid Esperantist, saw parallels between his own thought and Ogden's, but ultimately remained sceptical of Basic. Neurath, however, embarked on a collaboration with Ogden, in the course of which he drew out the common threads in the philosophy and goals of his system of picture statistics and Ogden's Basic. The recurring motif in this exchange is the 'everyday': amid their differences, all three looked to everyday experience as the anchor that would prevent their philosophy from drifting off into 'metaphysics', and all three, to varying degrees, hoped to use their work to improve everyday life. Additionally, for Ogden and Neurath, everyday language occupied a special place in these efforts. We see in this episode an example of the social engagement of those associated with the Vienna Circle that has long been underplayed and only come to prominence in recent historical work (e.g. Haller 1993; Cartwright et al. 1996; Giere and Richardson 1996; Stadler 1997; Reisch 2005; Uebel 2008). We also see the important place the international language movement occupied in the consciousness of this era, one aspect of the age which remains largely unnoticed in modern historical scholarship.

\section{References.}

Beaney, Michael. 'Susan Stebbing on Cambridge and Vienna Analysis', in Stadler (2003) 339-350.

Blanke, Detlev. Internationale Plansprachen: eine Einführung (Berlin: Akademie-Verlag, 1985).

\section{—. Interlinguistische Beiträge: zum Wesen und zur Funktion internationaler Plansprachen}

(Frankfurt am Main: Peter Lang, 2006).

Burke, Christopher. 'The Linguistic Status of Isotyp', in Image and imaging in philosophy, science and the arts, vol. 2, edited by Richard Heinrich, Elisabeth Nemeth, Wolfram Pichler, David Wagner (Frankfurt: Ontos Verlag, 2011) 31-57. 
Carnap, Rudolf. 'Über Protokollsätze', Erkenntnis 3 (1932): 215-228.

—. The Unity of Science. (London: Kegan Paul, 1934). (Translation by Max Black of 'Die physikalische Sprache als Universalsprache der Wissenschaft'. Erkenntnis 2 (1931): 432465.)

—. 'The Rejecton of Metaphysics'. Psyche 14 (1934): 100-111.

—. Philosophy and Logical Syntax. (London: Kegan Paul, 1935).

—. Logical Syntax of Language. (London: Kegan Paul, 1937). (Translation by Amethe Smeaton of Logische Syntax der Sprache. Vienna: Springer, 1934.)

—. 'The elimination of metaphysics through logical analysis of language', in Logical Positivism, edited by A.J. Ayer (Glencoe, Illinois: The Free Press, 1959) 60-81 (Translation by Arthur Pap of 'Überwindung der Metaphysik durch logische Analyse der Sprache'. Erkenntnis 2 (1931): 219-241. )

-. 'Intellectual Autobiography', in The Philosophy of Rudolf Carnap, edited by Paul Arthur Schilpp (La Salle, Ill.: Open Court, 1963) 3-84.

Cartwright, Nancy, Jordi Cat, Lola Fleck and Thomas E. Uebel. Otto Neurath: philosophy between science and politics (Cambridge: Cambridge University Press, 1996).

Carus, A.W. Carnap and twentieth-century thought (Cambridge: Cambridge University Press, 2007).

Cohen, Robert S. and Marie Neurath. Otto Neurath: philosophical papers 1913-1946 (Dordrecht: Reidel, 1983).

Fabian, Reinhard. 'The Otto Neurath Nachlass in Haarlem', in Nemeth and Stadler (1996) 337-356.

Forster, Peter G. The Esperanto Movement (The Hague: Mouton, 1982).

Gesellschafts- und Wirtschaftsmuseum Wien. Gesellschaft und Wirtschaft: bildstatistisches 
Elementarwerk (Leipzig: Bibliographisches Institut, 1930).

Giere, Ronald N. and Alan W. Richardson (eds.) Origins of Logical Empiricism (Minneapolis: University of Minnesota Press, 1996).

Haller, Rudolf. Neopositivismus. Eine historische Einführung in die Philosophie des Wiener Kreises (Darmstadt: Wissenschaftliche Buchgesellschaft, 1993).

Haller, Rudolf and Robin Kinross (eds.) Otto Neurath: Gesammelte bildpädagogische Schriften. (Vienna: Hölder-Pichler-Tempsky, 1991).

Haupenthal, Reinhart. Über die Startbedingungen zweier Plansprachen: Schleyers Volapük (1879/80) und Zamenhofs Esperanto (1887) (Schliengen: Edition Iltis, 2005).

Lockhart, Leonora Wilhelmina. 'Word formation', Psyche 9 (1928) No.2: 8-12.

—. Word Economy (London: Kegan Paul, 1931a).

—. 'Critical Discussion', Psyche 11 (1931b) No.3: 81-88.

Milkov, Nikolay. 'Susan Stebbing's criticism of Wittgenstein's Tractatus', in Stadler (2003) 351363.

Müller, Karl H. 'Neurath's theory of pictorial-statistical representation', in Rediscovering the Forgotten Vienna Circle: Austrian studies on Otto Neurath and the Vienna Circle, edited by Thomas E. Uebel (Dordrecht: Kluwer, 1991) 223-251.

Myers, Adolph. Basic and the Teaching of English in India (Bombay: The Times of India Press, 1938).

Nemeth, Elisabeth and Friedrich Stadler (eds.) Encyclopedia and Utopia: The life and work of Otto Neurath (1882-1945) (Dordrecht: Kluwer, 1996).

Neurath, Marie und Robert S. Cohen (eds.) Empiricism and Sociology (Dordrecht: Reidel, 1973). 
Neurath, Marie and Robin Kinross. The Transformer: principles of making Isotype charts (London: Hyphen Press, 2009).

Neurath, Otto. 'Physicalism: the philosophy of the Viennese Circle', The Monist 41 (1931): 618-623 (Reproduced in Cohen and Neurath 1983: 48-51).

—. Isotype: international picture language (London: Kegan Paul, 1936).

—. Basic by Isotype (London: Kegan Paul, 1937).

—. 'Unified Science as Encyclopedic Integration', in Encyclopedia and Unified Science, vol. 1, edited by Otto Neurath, Niels Bohr, John Dewey, Bertrand Russell, Rudolf Carnap and Charles W. Morris (Chicago: University of Chicago Press, 1938) 1-27.

—. Modern Man in the Making (New York: Knopf, 1939).

—. 'Protocol Statements', in Cohen and Neurath (1983) 91-99 (Translation by Robert Cohen of 'Protokollsätze', Erkenntnis 3 (1932): 204-214).

—. 'The Orchestration of the Sciences by the Encyclopedism of Logical Empiricism', in Cohen and Neurath (1983) 230-242 (Original in Philosophy and Phenomenological Research 6 (1946): 496-508).

—. 'Unified Science and Psychology', in McGuinness (1987) 1-23 (Translation by Brian McGuinness of Einheitswissenschaft und Psychologie (Vienna: Gerold and Co., 1933).

—. 'Gesellschafts- und Wirtschaftsmuseum in Wien', in Haller and Kinross (1991) 1-17 (Original in Österreichische Gemeindezeitung 2 (1925): 16.1-155).

—. 'Die Tätigkeit des Gesellschafts- und Wirtschaftsmuseums in Wien', in Haller and Kinross (1991) 34-39 (Original in Österreichische Gemeindezeitung 3 (1926) No.10: 324-327.)

—. 'Bildstatistik nach Wiener Methode in der Schule', in Haller and Kinross (1991) 265-336 (Original: Bildstatistik nach Wiener Methode in der Schule. Vienna: Deutscher Verlag für 
Jugend und Volk, 1933).

—. 'Isotype und die Graphik', in Haller und Kinross (1991) 342-354 (Translation by Rudolf Haller of 'Isotype en de graphiek', De Delver 9 (1935) No.2: 17-29.)

—. 'Visual education: humanisation versus popularisation', in Nemeth and Stadler (1996:245-335).

—. From Hieroglyphics to Isotype: a visual autobiography (London: Hyphen Press, 2010).

Ogden, Charles Kay. 'Orthology (Editorial)', Psyche 8 (1927) No.1: 1-7.

—. 'The Universal Language (Editorial)', Psyche 9 (1929a) No.3: 1-9.

—. 'Editorial', Psyche 10 (1929b) No.2: 1-38.

—. Debabelization (London: Kegan Paul, 1931).

—. Jeremy Bentham: 1832-2032 (London: Kegan Paul, 1932a).

—. Bentham's Theory of Fictions (London: Kegan Paul, 1932b).

—. Basic English: a general introduction with rules and grammar (London: Kegan Paul, 1933) (First edition 1930).

—. Basic English versus the Artificial Languages (London: Kegan Paul, 1935).

—. 'Can Basic English be a World Language?' Picture Post, 23 October 1943: 23-25.

Ogden, Charles Kay and Ivor Armstrong Richards. The Meaning of Meaning (San Diego: Harcourt Brace Jovanovich, 1989) (First edition 1923).

Pietarinin, Ahti-Veikko. 'Principles and Practices of Neurath's Picture Language', in Otto Neurath and the Unity of Science, edited by John Symons, Olga Pombo and Juan Manuel Torres (Dordrecht: Springer, 2011) 71-82.

Reisch, George A. How the Cold War transformed philosophy of science: to the icy slopes of logic. (Cambridge: Cambridge University Press, 2005).

Richards, Ivor Armstrong. Basic English and its Uses. (London: Kegan Paul, 1943). 
Russell, Bertrand. Analysis of Mind (London: Allen and Unwin, 1921).

Schubert, Klaus. 'Interlinguistics - its aims, its achievements, and its place in language science', in Interlinguistics: aspects of the science of planned languages, edited by Klaus Schubert, in collaboration with Dan Maxwell (Berlin: Mouton de Gruyter, 1989) 7-44.

Schumann, Wolfgang. 'Memories of Otto Neurath', in Neurath und Cohen (1973) 15-18.

Stadler, Friedrich. Studien zum Wiener Kreis. Ursprung, Entwicklung und Wirkung des Logischen Empirismus im Kontext (Frankfurt am Main: Suhrkamp, 1997) (English translation [not consulted in writing this paper]: The Vienna Circle. Studies in the Origins, Development and Influence of Logical Empiricism. Vienna: Springer, 2001).

- (ed.) The Vienna Circle and Logical Empiricism: re-evaluation and future perspectives (Dordrecht: Kluwer, 2003).

Stebbing, L. Susan. 'Logical Positivism and Analysis', Proceedings of the British Academy of Sciences 19 (1933): 53-87.

Uebel, Thomas. Empiricism at the Crossroads. The Vienna Circle's Protocol Sentence Debate (Chicago: Open Court, 2007).

—. 'On the production, history, and aspects of the reception of the Vienna Circle's manifesto ', Perspectives on Science 16.1 (2008): 70-102.

Verein Ernst Mach. 'Wissenschaftliche Weltauffassung: der Wiener Kreis', in Wiener Kreis, edited by Michael Stöltzner and Thomas E. Uebel (Hamburg: Felix Meiner Verlag, 2006) 1-29 (Original published Vienna: Artur Wolf, 1929).

Walpole, H. 'The Theory of Definition and Its Application to Vocabulary Limitation', The Modern Language Journal 21 (1937): 398-402. 
Wisdom, John. ‘Analysis and Interpretation', Psyche 11 (1930) No.2: 11-31.

—. Interpretation and Analysis (London: Kegan Paul, 1931).

Wittgenstein, Ludwig. Tractatus Logico-Philosophicus (London: Kegan Paul, 1922).

Zamenhof, Ludwig Lazarus. Dr Esperanto's International Language, Introduction and Complete Grammar (Warsaw: self-published, 1889) (Translation by Richard H. Geoghegan of Международный языкъ : Предисловіе : Полный учебникъ por Rusoj. Warsaw: selfpublished, 1887).

—. Fundamento de Esperanto (Paris: Hachette, 1905). 